\title{
Teachers' Competence in Creating Classroom Action Research (CAR) Proposal
}

\author{
Ikhsan Abdul Latif ${ }^{1}$, Dewi Retno Sari $\mathrm{S}^{1}$, Riyadi $^{1}$ \\ ${ }^{1}$ Mathematics Education Department of Graduate Program \\ Sebelas Maret University, Surakarta, Indonesia \\ Email:al_ikhsan@student.uns.ac.id
}

\begin{abstract}
Reflection of the learning process is evaluation activities undertaken by a teacher to determine the deficiencies and weaknesses of learning activities that have been done. One effort to overcome these deficiencies and weaknesses is to do Classroom Action Research (CAR). CAR can improve the quality of learning. In addition, CAR is one of the promotion requirements for Civil Servant teacher. In fact, teachers have difficulty to do CAR. The main difficulty is creating a proposal which caused by the lack of teachers' knowledge about the theories of CAR. This study determines the teacher's knowledge of the theories of CAR and their competence in creating the CAR proposal. This study was conducted by interview and observing CAR proposal of a Maths Civil Servant teacher in SMAN 1 Wuryantoro, Wonogiri Regency. The results of this study are Maths Civil Servant teacher in SMAN 1 Wuryantoro, Wonogiri Regency less understands about the theories of CAR. However, he has a good competence in creating the CAR proposal.
\end{abstract}

Keywords: teacher's competence; Classroom Action Research (CAR); theories of CAR; CAR proposal

\section{INTRODUCTION}

Every teacher is obligated to achieve the national teachers standards of academic qualification and competence [1]. Professional teachers are teachers who carry out all of the competence of the teacher. The teachers competence in Indonesia is divided into four, namely pedagogic, personality, social, and professional competence [2]. The competence which directly impacts to the students is pedagogic and professional competence. Pedagogic competence is the ability of teachers in understanding, designing and implementing student learning, evaluating the results of the study, and developing the potential of students. Professional competence is the ability of teachers in mastering the learning materials and the substance of science that shelter them. 
One of the teachers' pedagogic competence is a reflective action for the improvement of the quality of learning, whereas professional competence required the teachers to develop their professionalism with a reflective action. Reflective action can be done by reflecting the learning activities that have been done. Teachers can know the weakness of learning activities by doing reflection learning activities. These weaknesses can be overcome by doing CAR. For the purposes of learning implementation, through the relevant educational institutions, the government has to equip teachers with the CAR training to improve the learning quality [3].

Action research is a form of enquiry that enables practitioners everywhere to investigate and evaluate their work [4]. CAR is practical research that conducted by a teacher to correct and improve the quality of learning. In addition, the CAR aims to solve the learning problems at school. CAR is also a requirement to obtain a profession certificate of educator and teacher's promotion. In fact, teachers feel difficulty in performing CAR. Many teachers complain because of the obligations performing CAR. The teachers also have less knowledge of the theories of CAR, so they have the difficulties in creating the proposal CAR. The cause of the low level of teachers competence in making the proposal is 1) lack of the teachers' competence in the areas of CAR, 2) teachers' poor understanding of the benefits of the CAR, 3) lack of teachers' competence in CAR, 4) lack of CAR products produced by the teachers, 5) only a few number of teachers to be promoted within the last 3 years [5].

\section{LITERATURE REVIEW}

\section{Classroom Action Research (CAR)}

CAR is a practical research that conducted by a teacher to correct and improve the quality of learning. CAR also aims to solve the learning problem at school. CAR is one way that can be used by teachers to understand the problems occurring in the classroom and to know how to do solve them [6]. CAR is a method of finding out what works best in your own classroom so that you can improve student learning [7].

\section{THE BASIC PRINCIPLES OF CAR}

The basic principles of the CAR and things that need to be considered by the researchers (teachers) are [8]

a. CAR is oriented on educational improvements by doing the changes that implemented in the actions. The readiness of teachers to change is an important requirement when will make improvements.

b. The CAR problem has to be a problem that does exist, factual, be interesting, and deserves to be examined. We recommend starting CAR with simple things and real. Therefore, the cycle begins with the small things so that planning, implementation, observations, and reflections became more obvious. 
c. The CAR methodology has to be precise and reliable. If the metodology is appropriate, then it will provide opportunities for teachers to formulate a hypothesis of action and develop a strategy that can be applied in their classroom.

d. CAR is a systematic (every phenomenon has linkages with other phenomena), measurable (the research results described with indicators), and objective (based on the actual circumstances without the intervention of researchers subjectivity) process that requires intellectual abilities and skills. When the research process, researchers are required to think critically that is beginning to determine a problem, planning actions (either theoretical or practical), then described in the actions.

e. The topics developed related to the effectiveness of the teaching method used by the teacher over the years.

f. CAR not only presents a tendency of teacher's teaching method based on classes and subjects, but also reflect the ability of teachers in writing scientific papers as part of enhancing teacher professionalism.

\section{THE STEPS OF CAR}

CAR steps commonly called Research Cycle are planning, implementation, observation, and reflection [9].

a. Planning

At this step, the researchers explain the what, why, where, when, and how research is done. Research should be done collaboratively, so that it can reduce the element of subjectivity.

b. Implementation

This step is the implementation of the activities of planning actions in the classroom that became the subject of research. In this implementation of activities, teachers (researchers) have to obey over the plan that has been prepared. Keep in mind that the implementation or practice of this research goes as usual when conducting learning before the research, it should not be contrived that caused learning to be rigid. Collaborators suggested doing observations objectively that appropriate to the conditions of the study conducted by the researchers.

c. Observation

At this step, there are two observed activities, namely, students learning and learning activities. Observation of the students learning process can be done by implementing teacher (researcher) while carrying out the study, however, the observation of the learning process are necessarily carried out by collaborators.

d. Reflection

The reflection activities are carried out when the collaborators have already finished observing the researcher while carrying out the study, then dealing with the researcher to discuss the observations results when researcher perform the implementation of the action plan. 


\section{The Writing System of The CAR Proposals}

The writing system of the CAR proposal used in this study refers to Panduan Pelaksanaan Program Penelitian Tindakan Kelas Tingkat Satuan Pendidikan Tahun 2016, published by the Ministry of Education and Culture.

The CAR proposal must be written between 15 to 20 pages use A4 paper with margins of $3 \mathrm{~cm}$ left, $2.5 \mathrm{~cm}$ top, $2.5 \mathrm{~cm}$ right, $3 \mathrm{~cm}$ buttom, the font is Times New Roman spacing 1.5 [10].

\section{THE FRONT SECTION OF THE PROPOSAL}

The front of the CAR proposal contains about title page, approval page, preface, table of contents [11].

a. Title Page

Short, specific, and it is quite clear to describe the issue that will be examined, action to resolve it, the expected results, and the place of research.

b. Approval Page

Signed by the chairman of the researcher, the headmaster, and supervisor or a companion (if any) as a description that the CAR report has met the requirements.

c. Preface

Explain why this CAR problem was raised as a research topic, environmental factors that give importance to research, the position of the CAR in problem-solving learning, and a flash of hope to those who read the research report.

d. Table of Contents

\section{THE CONTENT SECTION OF THE PROPOSAL}

The content section contains three important chapters, namely, introduction, literature review, methodology and research [12].

a. Introduction

1) Background

The background describes straightforwardly problems, the causes of the problems, and the level of problems that want to be solved by researcher. In the background is also necessary to explain that the the problem studied are trully real and are within in the teacher's authority and supported by the theories and results of previous research.

2) Identification and Restriction Problems

Problem identification is the introduction of a problem. Research problem can be found through the study of literature or observation (survey, observation, etc.). Based on the various issues further held the limitation issue where the only concern in the CAR.

3) Research Purposes

Research objectives that will be achieved (general and specific) are clearly formulated according to the proposed problem, so that they show the level of 
effectiveness (or ineffectiveness) of a particular treatment so that it becomes a valuable information to refine the rules or practice of learning.

4) Research Benefits

In CAR, teacher or researcher indirectly will develop learning tools that are coherent with the underlying theory of the action. Define the benefits of these learning tools are related to the effort of learning improvement. In addition, teacher or researcher will successfully explore or uncover data findings or empirical facts. Predict the empirical data or facts and formulate the benefits. All the benefits that have been formulated are specified for students, teachers, researchers, schools, or other interested parties.

b. Literature Review

Literature review discuss the theoretical and empirical studies reported in journals, magazines, websites, textbooks or previous research report, in line with the formulation and hypothesis of action.

c. Research Methodology

Research methodology describe the research steps that will be done in detail, ranging from planning, implementation of the action, observation, evaluation, and reflection that are cyclical.

d. Bibliography

Bibliography written consistently according to the APA, MLA, or Turabian models.

e. Life History of Researcher

List of relevant research experience to date (if any).

\section{METHOD}

This study is a qualitative research using case study strategy to know teacher competence in making CAR proposal. The competencies in question are about teacher's understanding of CAR theories and the ability to draw up a CAR proposal. The case study is a detailed testing of a background or a subject or a document storage or a specific event [13]. The subject in this study is a Maths Civil Servant teacher in SMAN 1 Wuryantoro, Wonogiri Regency.

Researcher did in-depth interviews with the teacher to find out his understanding of the CAR theories. The researcher asks about the definition, basic principles, and steps of CAR.

To know the ability of teachers in creating the proposal for CAR, researcher analyzes a teacher's proposal whether it is appropriate to the Panduan Pelaksanaan Program Penelitian Tindakan Kelas Tingkat Satuan Pendidikan Tahun 2016. 


\section{RESULTS AND DISCUSSION}

The learning reflection is the activity of teachers in evaluating the learning activities that have been done. Reflection learning aims to determine the shortcomings of learning that has been done. CAR is the one way to solve deficiencies and improve the quality of learning. CAR also aims to solve learning problems at school.

This research used in-depth interviews and analyzed a CAR proposal of Maths Civil Servant teacher in SMAN 1 Wuryantoro, Wonogiri Regency. Interview aims to determine the competence of teachers in understanding CAR theories that consist of understanding, principles, and stages of CAR. The analysis of the CAR proposal document aims to determine the suitability of the document with the CAR guidelines. So that, what is meant by the competence of teachers in creating CAR proposal is 1) understanding CAR theory consisting of the definition, principles, and steps of CAR and 2) creating a CAR proposal that appropriate to the Panduan Pelaksanaan Program Penelitian Tindakan Kelas Tingkat Satuan Pendidikan Tahun 2016.

Based on the interview results, obtained that the teacher is less understanding the CAR theories. The teacher said that CAR is a step to improve learning process because of the learning problems in the classroom. CAR is only apllies to a certain class and can not be generalized. The teacher can not explain the principles of CAR. The reason of the teacher do a CAR is the demand that teachers should do the Sustainable Development of Profession.

According to the teacher, there are 4 steps of CAR that are identifying the problem, determining problem-solving, trying the steps, and writing the activities. In the identifying problem step, the teacher makes observations and interviews with the students to identify their learning difficulties. In determining problem-solving step, teacher looks for references that appropriate to the students and classroom's conditions. In trying the step, the teacher applies the problem-solving step according to the students' condition. The final stage is writing the activities where the teacher prepares a report on the activities that have been done.

This study analyzes the proposal document entitled Penerapan Model Pembelajaran Kooperatif Tipe Jigsaw Pada Materi Kaidah Pencacahan Untuk Meningkatkan Prestasi Belajar Matematika Siswa Kelas XI IPS SMA N 1 Wuryantoro Tahun Pelajaran 2016/2017. Based on the results of the CAR proposal analysis obtained that CAR proposal of Maths Civil Servant teacher in SMAN 1 Wuryantoro, Wonogiri Regency has been appropriate to the guidelines. However, the margin and chapter titles do not apply and there are some unsuitable chapters or sections and some explanatory points are not described. The CAR proposal uses margins $4 \mathrm{~cm}$ top, $4 \mathrm{~cm}$ left, $3 \mathrm{~cm}$ right, and $3 \mathrm{~cm}$ buttom.

\section{The Front Section of Teacher's Proposal}

The front section of the CAR proposal contains about title page, approval page, preface, and table of contents. 
a. Title and Approval Page

The title and approval page are in appropriate to the guidelines. The title is short, specific, and clear enough to describe the problem that will be researched, the action to solve it, the expected results, and the place of research. Approval page is signed by the teacher (researcher) and the headmaster.

b. Preface

The preface does not explain the origin of why the CAR problem was raised as a research topic, the environmental factors that gave significant to the research, and the CAR position in problem-solving learning. Teacher writes a thank-you to those who have helped, hope the research is useful for education and learning mathematics, and the hopes of criticism and suggestion to the reader.

c. Table of Contents

\section{The Content Section of The Teacher's Proposal}

The content section contains three chapters, namely introduction, grounded theory, and research methods.

a. Introduction

1) Background

The background has explained the problems that want to be solved, the causes of the problem, and the level of problem that the teacher wants to solve. The background also explains the theories and previous research results.

2) Identification and Restriction Problems

There is no identification and restriction problem. The sub-section after background is the formulation of the problem.

3) Research Purposes

The purpose of the research does not appropriate to the guidelines. The research purposes do not lead to the improvement of learning and are not suitable if it is used as the CAR goals.

4) Research Benefits

The research benefits have been appropriate to the guidelines. The teacher divides the research benefits into two, namely the practical and theoretical benefits. The practical benefits are sub-divided into four that are educational institutions, teachers, students, and the library.

b. Grounded Theory

The grounded theory discusses literature review, relevant research results, and the frame of mind. The grounded theory is in appropriate to the guidelines, however, the writing of the chapter titles do not appropriate to the guidelines.

c. Research Method

The research method is appropriate to the guidelines. Research method describes the steps of research that will be done. That are planning, an action, observation, and reflection. However, it is not describe yet the evaluation 
activities. In addition, the research method described research settings that include the time and place of research, the research subject, data sources, data collection methods, types and tools of data collection, data collection thecniques, data validation, data analysis, conclusion drawing technique and performance indicators.

d. Bibliography

The bibliography is written according to APA model.

\section{CONCLUSION}

CAR is the one way to solve deficiencies and improve the quality of learning. CAR also aims to solve learning problems at school. Thus, the important component of the CAR is the competence of teachers in conducting CAR. This study aims to determine the competence of teachers in creating CAR proposal. Teacher competence in creating CAR proposal is the teacher's ability in understanding CAR theory (definition, principles, and step of CAR) and creating CAR proposal according to Panduan Pelaksanaan Program Penelitian Tindakan Kelas Tingkat Satuan Pendidikan Tahun 2016.

Based on the interview results, obtained that the teacher is less understanding the CAR theories. The teacher said that CAR is a step to improve learning process because of the learning problems in the classroom. CAR is only apllies to a certain class and can not be generalized. The teacher can not explain the principles of CAR. The reason of the teacher do a CAR is the demand that teachers should do the Sustainable Development of Profession. According to the teacher, there are 4 steps of CAR that are 1) identifying the problem, 2) determining problem-solving, 3) trying the steps, and 4) writing the activities.

Based on the results of the CAR proposal analysis obtained that CAR proposal of Maths Civil Servant teacher in SMAN 1 Wuryantoro, Wonogiri Regency has been in appropriate to the guidelines. However, the margin and chapter titles do not apply and there are some unsuitable chapters or sections and some explanatory points are not described. The parts of the proposal that are not appropriate to the guidelines are 1) the preface does not explain the origin of why the CAR problem was raised as a research topic, the environmental factors that gave significant to the research, and the CAR position in problem-solving learning, 2) there is no identification and restriction problems (the sub-section after background is the formulation of the problem), 3) research purposes do not lead to the improvement of learning and are not suitable if it is used as the CAR goals, 4) the writing of chapter the titles of literature review is not appropriate to the guidelines, however the content of the literature review have been appropriate to the guidelines. 


\section{REFERENCES}

[1] The Regulation of the Minister of Education Number 16 of 2007 on Teachers' Academic Qualification Standars and Competencies.

[2] Law of the Republic of Indonesia Number 14 of 2005 on Teachers and Lecturers.

[3] Sadimin, Wahyu Hardyanto, Achmad Slamet, and Titi Prihatin. 2017. "Developing an E-ModuleBased Classroom Action Research Management Training Model for Teacher High School," International Journal of Education and Reseacrh, 5(2), p 80.

[4] Jean McNiff \&Jack Whitehead. 2006. All You Need to Know about Action Reseach. SAGE Publication, $\mathrm{p} 7$.

[5] Sadimin, Wahyu Hardyanto, Achmad Slamet, and Titi Prihatin. 2017. "Developing an E-ModuleBased Classroom Action Research Management Training Model for Teacher High School," International Journal of Education and Reseacrh, 5(2), p 80.

[6] Sadimin, Wahyu Hardyanto, Achmad Slamet, and Titi Prihatin. 2017. "Developing an E-ModuleBased Classroom Action Research Management Training Model for Teacher High School," International Journal of Education and Reseacrh, 5(2), p 79.

[7] Gwynn Mettetal. 2001. "The What, Why, and How of Classroom Action Research," The Journal of Scolarship of Teaching and Learning, 2 (1), p 7.

[8] Pusat Penelitian Kebijakan Badan Penelitian dan Pengembangan. 2015. Panduan Pelaksanaan Program Penelitian Tindakan Kelas Tingkat Satuan Pendidikan Tahun 2016. Kementerian Pendidikan dan Kebudayaan, pp 4-5.

[9] Sunardi and Imam Sujadi. 2016. Sumber Belajar Penunjang PLPG 2016 Materi Pedagogik BAB XIX Refleksi Pembelajaran dan PTK. Kementerian Pendidikan dan Kebudayaan, pp 16-18.

[10] Pusat Penelitian Kebijakan Badan Penelitian dan Pengembangan. 2015. Panduan Pelaksanaan Program Penelitian Tindakan Kelas Tingkat Satuan Pendidikan Tahun 2016. Kementerian Pendidikan dan Kebudayaan, p 6.

[11] Pusat Penelitian Kebijakan Badan Penelitian dan Pengembangan. 2015. Panduan Pelaksanaan Program Penelitian Tindakan Kelas Tingkat Satuan Pendidikan Tahun 2016. Kementerian Pendidikan dan Kebudayaan, $\mathrm{p} 19$.

[12] Pusat Penelitian Kebijakan Badan Penelitian dan Pengembangan. 2015. Panduan Pelaksanaan Program Penelitian Tindakan Kelas Tingkat Satuan Pendidikan Tahun 2016. Kementerian Pendidikan dan Kebudayaan, pp 19-20.

[13] R. C Bogdan and S. K Biklen. 1982. Qualitative Research for Education: An Introduction to Theory and Mehtods. Allyn and Bacon, Inc. 